\title{
THE INTERNMENT OF JAPANESE AMERICANS DURING WORLD WAR II: A CASE STUDY OF NATIONAL TRAUMA AND INSTITUTIONAL VIOLENCE
}

\author{
Dr Ridwan Laher ${ }^{*}$, Subject Group Political Science (Mil), \\ Faculty of Military Science, Stellenbosch University \\ and \\ Prof Arthur G. Neal, Emeritus Distinguished Professor of \\ Sociology, Bowling Green State University, and Adjunct \\ Professor of Sociology, Portland State University
}

\section{Introduction}

The events set in motion by the Japanese bombing of Pearl Harbour were among the more consequential events in the history of the world (Toland, 1982). The subsequent development of the atomic bomb and its use at Hiroshima and Nagasaki permanently changed the conditions under which men and women live (Selden and Selden, 1989) and provided a dramatic illustration of what human beings are capable of doing to each other (Lifton and Markusen, 1988). The immediate effects of the surprise attack on the United States (US) were traumatic as the nation entered a war for which it was not prepared. The long range-effects include the imprinting of the surprise attack in collective memories and a national determination by the US to never again be caught unprepared militarily (Neal, 2005). Both political leaders and journalists drew upon the memories of Pearl Harbour as they attempted to make sense out of the surprise terrorist attack of September 11, 2001 (9/11), and to mobilize the nation for an effective response.

The decision by the Empire of Japan to plan for and to carry out an attack on Pearl Harbour brought with it extreme social and political disruptions within the US. Americans pondered the question of why their military commanders were so unprepared at Pearl Harbour (Prange, 1982) and struggled to understand how and

\footnotetext{
* The author is also known as Ridwan Laher Nytagodien.
} 
why such a vicious attack would, and could, be carried out against the US. All of a sudden questions about what it meant to be an American were raised in an attempt to reconfirm the glory and status of the nation-state in the international system. As the shock settled into the psyche of the nation-state, an account of the civilian and military losses suffered brought with it further disbelief that evoked rising levels of anger, mass hysteria, and calls for comprehensive retaliation.

This paper applies the concept of a national trauma to the responses of Americans after the Japanese attack on Pearl Harbour. The purpose is to analyse the process by which the surprise attacks precipitated collective sadness, fear, and anger that resulted in mass hysteria as Americans called for revenge. What follows then is an interdisciplinary case study that develops out of a growing interest in the conceptual linkages between individual and collective traumas. A perusal of the developing literature will find studies that underscore trauma linkages to persistent inequalities in the social and political (socio-political) life of the nation-state. The trauma linkage, for example, between slavery and persistent racism toward African Americans (blacks) in contemporary US political life is frequently explored (Robinson, 2000). In South Africa attention has been placed on the role of the Truth and Reconciliation Commission (TRC) to address socio-political change and trauma consequences in the post-apartheid state (Nytagodien, 2002). The same is true for studies that focus on trauma and collective memory as it relates to nation-state challenges in Rwanda (Berry and Berry, 1999), the former Zaire (Hochchild, 1999), Japan (Igarashi, 2000), Mexico (Benjamin, 2000), among others.

The formative assumption of this paper is that the attack on Pearl Harbour induced a collective national trauma from the US being caught unaware and unprepared. The US made the tactical mistake of underestimating Japan's political will to attack and their ability to carry out such an attack. For reasons that are still hotly debated today, Americans faltered by developing stereotypes of the Japanese as mentally inferior and lacking in the capability of developing a sophisticated technological undertaking (Benedict, 1989). This dismissive, and ultimately costly attitude drew on a well-worn racist depiction of Asians, and specifically the Japanese, as being a racially inferior people. As a result, the US, its leaders, the navy and the military establishment as a whole, ignored the real threat Japan posed to its national security. When the attack did occur, the trauma of surprise and shock extended throughout the nation.

Pearl Harbour brought with it severe socio-political consequences that were far reaching (Neal, 2005). Mass hysteria and collective anger fuelled hatred 
toward people of Asian ancestry living in the US. The federal government moved to suspend the constitutional rights of citizens of Japanese descent. This vindictive political punishment caused Japanese Americans to suffer consequential structural losses of property and assets. They also found themselves the victims of racial hostility and violence that brought with it severe psychological and physiological damage. It is purposeful and valuable to review the case of Pearl Harbour because it provides us with theoretical and applicative insight into the content and place of national trauma in the contemporary life of the American nation-state, and of nationstates in general. It cannot be ignored that the terrorist attacks of $9 / 11$ bear a remarkable resemblance to the context and aftermath of Pearl Harbour. Both traumas found the American people simply reeling in disbelief. Additionally, the national responses to both traumas are seated in complex socio-political circumstances. Thus, the attention being paid to Pearl Harbour here is intended to spark debate on the place of collective trauma in the life of modern nations.

In this analysis, the second formative assumption is that the concern with national security and problems of espionage were less directly involved in the incarceration of Japanese Americans than racism and a desire for revenge against the Empire of Japan. The primary concern here is with the institutional violence that was directed at Japanese Americans. For this reason, the elements that relate to the psychology and socio-political contexts of institutional violence are highlighted. The primary analytical framework will consist of extending the psychological concept of trauma to the shared or collective experiences of the American nationstate.

\section{Theorising national trauma}

Trauma as a concept is usually used to characterize and explain a shocking and abnormal personal event (Herman, 1997). The trauma of rape victims, abused spouses, victims of racist violence, war veterans, holocaust and genocide survivors, are among the experiences that typify the application of the concept. At the core of a trauma is an inimical episode that elicits consequential disruption and pain. The victim is dumbfounded and explicitly shocked by the unexpected nature of a trauma. Their life is laid bare and the consequences bring a spontaneous and radical realignment that cannot be ignored or easily set aside.

The victim of a trauma may exhibit an array of maladaptive psychiatric components such as estrangement, detachment, eating disorders, amnesia, psychological numbness, sleep disorders, among others. Whatever the maladaptive 
response, s/he is forced into an acute personal crisis that revolves around feelings of hopelessness and despair. Inside of this crisis, the victim may raise overwhelming questions about the meaning of life, their place in the social order, and the value of living. This existential crisis presses against the need to restructure their selfidentity and social place as a basis of restoring order and a sense of normalcy.

In recent years, the concept of trauma has been theoretically developed and applied to the collective experiences of groups of people that include the nationstate (Neal, 2005). In the case of groups, the nature of the trauma is collective instead of personal or individual. The injury in a national trauma comes as a result of a fusillade on the social and political (socio-political) life of the nation-state as the 9/11 terrorists attacks in the US exemplifies. Interestingly, both collective and personal traumas exhibit similar maladaptive psychiatric responses. In either trauma, the victims are left with feelings of disbelief and incredulity as they struggle to make sense out of the abnormal event(s) that precipitated in a very short period of time (Herman, 1997).

National traumas, however, are distinctive for the reason that they provoke chaos among the citizenry. People are shocked and taken by surprise as they frenetically rush to garner information about the course and content of the traumatic event. In the case of the 9/11 terrorists attacks, for example, Americans sat glued to their televisions watching every shred of footage and listening closely to news analysts from cable news networks like CNN and MSNBC, as well as the domestic broadcasters ABC, NBC, CBS, and PBS (Silberstein, 2002). A defining characteristic of a collective national trauma is the manner in which the citizenry assemble and distribute information about the traumatic event from competing sources in the public and private spheres (Altheide, 2002). Accurate and inaccurate information are meshed together in terms that exceed the narrow brunt of a personal trauma. For all intents and purposes, a collective national trauma is an extraordinary event in the life of the nation-state (Browne and Neal, 2001). No corner of the nation-state is exempt from the consequences that arise.

Inside of the frenzy to make sense of what has just taken place, the nationstate is submerged into circumstances that are chaotic. Citizens are uncertain about what to believe and what not to believe. There may be confusion about the interrelatedness of events that precede and follow the traumatic event. This uncertainty raises peculiar questions about the linkage of personal lives to the political circumstances that surround a trauma (Neal, 2005). People look toward their government for explanations, relief, and even solutions. Questions about the 
meaning and value of national life, the political system, and the sovereignty of the nation-state arise.

The victims of a national trauma are tied to the political life of the nationstate. They cannot simply rely entirely on their own resources to deal with the weight of the trauma. It is this political intimacy that draws the victims of a national trauma closer together to explore the meaning of the trauma and its consequences. The responses undoubtedly vary in relation to the character and size of the trauma. Victims, however, draw upon the common myths and history that bind the nationstate. In this way, the manner in which a nation-state responds is underscored by the meaning that is attributed to the trauma and its disruptive dislocation of the normal order inside the nation-state. The decision to act is often hinged on the need to reestablish order and a sense of pride. As in the case of a personal trauma, the victims of a national trauma also seek to rationalise the place and context of the trauma.

The effects of individual and national traumas are enduring. In the case of a national trauma, the consciousness that surrounds the traumatic experience dictates that it be addressed and not ignored. The conditions that surround a national trauma do not just disappear from consciousness but resurface as victims confront the disruption and its place in their lives (Nytagodien and Neal, 2004). As is the case with a personal trauma, a national trauma is permanent in effect and nature. The nation-state cannot just shrug off the changes brought by a national trauma in much the same way that an abused spouse or rape victim cannot forget or set aside the pain and consequences of their deplorable experiences. In effect, a national trauma changes the socio-political fabric of the nation-state forever.

\section{Hyper emotional arousal: America caught unawares}

Conditions of national trauma educe intense levels of emotionality as the predictability of socio-political worlds unravels and the normal lives of citizens are turned upside down. The hyper-emotional arousal from the Japanese attack on Pearl Harbour was shaped both by the severity of the tragedy and the cues that were received from both the news media and from interactions among citizens. Deep levels of sadness, fear, and anger soon replaced the initial shock. These responses grew out of bafflement, the encounter with chaos, and the attendant loss of coherence. Perceptions of evil reflected the frustration that morality and decency are not necessarily shared convictions. Because of the suffering associated with a tragic event, Americans were not able to remain emotionally detached or indifferent. 
As the nation-state navigated the sadness, collective anger and shock, it grew more fearful of additional Japanese attacks. The normal order and consistency of routines had been punctured and gave rise to interrelated levels of fear. The fear approximated mass hysteria as citizens began to worry about further attacks. Some expected the attack on Pearl Harbour to be followed by an invasion somewhere along the American West Coast (Daniels, 1975). Many expected bombing raids on American cities and towns. Rounds of rampant rumours began to surface about Japanese plans to invade the American West Coast. There were even rumours about sightings of Japanese planes, warships, submarines, and insurgents covering the geographical area between Alaska and California.

Media reports hyped up the fear among the citizenry by publishing fictitious reports that outlined Japanese plans for invading the West Coast of the US, or citing reports of enemy combatants entering the US. The news media also embellished the tragedy by detailing acts of heroism on the part of survivors and the deceased (Daniels, 1993). Inside of these reports Americans from all backgrounds struggled with what to believe and what not to believe. As rumours and hyped media reports circulated, assumptions about the likelihood of an invasion, or the course of the war, remained a matter of great uncertainty for all Americans. There was a heightened sense of urgency that something had to be done to restore a sense of order and normalcy. Americans looked to their government and leaders for answers and for solace.

The anger of Americans was made worse by the assumed knowledge that Japan had attacked without declaring war first. The truth was that the Japanese ambassador had tried to deliver the intention to declare war but was not able to secure an appointment with the State Department on a Sunday morning. The damage was done though, and even when the ambassador did deliver his message an hour after the attack, he was rebuffed. The incident was written off as a cowardly and devious act of deception. The long-standing racial images and stereotypes of the Japanese gained new and revitalized currency (McWilliams, 1944). They were seen now more than ever as people who could not be trusted. Their personalities were glossed over into cartoon-like caricatures of "squinty-eyed" deviants who were intent on ruling the world.

Mass hysteria spurned intense hatred and racial animosity toward all Asians whether Japanese or not. The troubled racial history of America was again inflamed but there were also questions that looked critically at the lack of preparedness of the armed forces (Hoehling, 1963). People wanted to know why the 
US was not prepared for war with Japan. Why its president, Franklin Roosevelt, and his military advisers had not intercepted intelligence that covered the intentions of the Japanese Empire (Rushbridger and Nave, 1992). The attack on Pearl Harbour brought home a few political truths that were not easy to swallow. The US had failed to develop an adequate awareness of the wars in Europe and Asia in terms of national security. Moreover, they underestimated the extent to which Japan viewed the role of the US as interfering with their objectives in the Pacific (Neuman, 1963). These objectives were clearly tied to Japan's plan to increase its influence in Asia. Already, Japan had invaded China and seemed set to expand its presence on the Chinese mainland.

The unprepared state of the US can also be partly attributed to its historical reluctance to become involved in WWI and WWII. This reluctance has roots that can be traced to President George Washington in his Farewell Address in 1796 where he advised the nation not to become involved in foreign wars (Spalding, 1998). Pearl Harbour came at a time when this isolationism was an ingrained part of American political thought. The American presidency primarily viewed the US disconnected from the wars in Europe and Asia. There was relative confidence that the geographic distance the US had from Europe and Asia meant their foreign wars would not become a domestic war. Additionally, the costs of being involved in the wars away from its shores were thought to be prohibitive. Congress was not prepared to commit to financing a military build-up.

Pearl Harbour thus found the US simply unaware and dumbfounded at the audacity of the Japanese (Hearings before the Joint Committee, 1946). Underestimating Japan and hanging onto isolationist principles found the US lacking and unable to withstand an attack on its soil. It now became clear that the US could not just stand by in world affairs and only selectively enter where it sought comparative advantage. Pearl Harbour consequently precipitated a radical realignment of its foreign policy posture. As the nation-state began to grapple with its response, it was also mired in questions about the meaning of the nation-state, its value, and the purpose of restoring its integrity. The mood in the country was undoubtedly one of revenge.

Listening to the news of the war evoked a combination of feelings of desperation, helplessness, and anger. Anything and everything seemed possible. The crisis was intensified by the speed with which the Japanese army had invaded Manila, Guam, Hong Kong, Shanghai, and Singapore. All of this was accomplished by the end of February 1942, less than three months after the attack on Pearl 
Harbour. The crisis was further intensified by news accounts of the conduct of the Japanese army in the countries that were occupied and, specifically, their cruel treatment of American prisoners of war. Japan seemed unstoppable and Americans sought immediate and effective action as the levels of panic and hysteria grew inside the US.

\section{The incarceration of Japanese Americans}

Approximately two-thirds of the Japanese Americans living on the West Coast were born in the US, and thus were citizens. They thought of themselves primarily as Americans, but like other ethnic groups they had retained their local heritage and aspects of lifestyles associated with their country of origin (Smith, 1948). Many had become successful businessmen and women, professionals, and farmers, who espoused one or the other version of the American dream. Although many were moving toward the American mainstream, and shared the nation's sense of shock, disbelief, and trauma emanating from the attack, sinister characteristics were imputed to all of them. Their Japanese ancestry was taken as obvious and direct evidence of collective guilt. Consequently, there was almost immediate outrage and hostility directed at Japanese Americans living on the West Coast.

As the need for news and reliable information exceeded the capability of the news gathering agencies, rumours about Japanese American complicity began to spread throughout the country. Rumours added fuel to the unsubstantiated speculation that Japan could not have been so successful in their attack on Pearl Harbour without the help of the Japanese living in Hawaii (Brown, 1989). Inside of the Japanese American community there were rumours that all persons of Japanese ancestry would be rounded up and shot (Shibutani, 1966). Overall, the rumour mill added fuel to the anxiety, fear, and uncertainty that gripped the American nation.

Conditions of trauma tap into the reservoir of emotions that lie beneath the surface of everyday life (Herman, 1996). This was clearly the case in the responses to the Japanese attack on Pearl Harbour. Anti-Japanese sentiments led to unrestrained emotional reactions that were intense but profoundly irrational. The need to construct Japanese Americans as enemy agents was set in motion by deepseated racial prejudice toward all Asians prior to the war. This characterisation now became ethically embellished and perceived as documented and justified (McWilliams, 1944). 
The combination of racism fuelled by anger produced a highly volatile situation. The consequences for Japanese Americans extended outside of the interpersonal realm into the arena of business and their professional lives. Banks in California refused to do business with Japanese Americans. Their accounts were frozen and they were not allowed to draw any money. Japanese Americans were turned away from grocery stores, convenience stores, and other basic service providers. The state of California rescinded the certification of doctors to practice medicine and of lawyers to practice law. Japanese Americans who owned businesses lost their customers and clients (Neal, 2005). The stigma of assumed betrayal was used to deprive Japanese Americans of the right to make a living and to live without fear of reprisals from angry mobs. Hardship and uncertainty grew as Japanese Americans struggled to provide basic necessities for themselves and their families.

Political leaders throughout the country joined pressure groups that were venting anger and calling for reprisals against Japanese Americans. Senator Tom Stewart joined congressmen John Rankin of Mississippi and Martin Dies of Texas in a campaign of racist rhetoric that was intended to advance their beliefs in white supremacy. Congressman Rankin, who was notoriously known for being anti-black and anti-semitic described World War II as a "race war" that inevitable pitted the "white man's civilization (against) Japanese barbarism" in a duel in which "one of them must be destroyed." He added that the Japanese "are pagan in their philosophy, atheistic in their beliefs, alien in their allegiance, and antagonistic to everything for which we stand." His comments were intended to caste suspicion onto Japanese Americans when he said: "Once a Jap always a Jap. You cannot change him. You cannot make a silk purse out of a sow's ear." Rankin's comments received ardent support from congressional leaders in Arkansas, Virginia, and West Virginia (Smith: 1991, pp.81-82).

The US government responded by taking charge of the interests of the nation-state in Realpolik terms. It sought to secure and maximize its power by singling out and containing threats to national security. Within just a few days after the bombing of Pearl Harbour, the US began a roundup of what it deemed "enemy aliens" living in the US. These "enemy aliens" numbered about three thousand men with a few women among them. About half of the roundups were Japanese aliens who under US immigration law could not naturalize to US citizenship. These men and women were considered dangerous and a threat to US national security. The federal government acted on guilt by association and arrested people of Japanese descent who were public officials, community leaders, and those who had some tie 
to the Japanese embassy and its consulates. The purpose was to remove anyone who could act as agents for the Japanese (Brookes, 1999).

General John L. DeWhitt, the Commanding General of the Western Defence, viewed Japanese Americans as enemies who would help Japan to invade the West Coast. In addition to espionage, there was a concern that Japanese Americans would be able to sabotage both military and civilian facilities within the US. Military officials expressed the apprehension that California's water system was highly vulnerable to an attack. They also raised concerns about the security of bridges and the vulnerability of wooded areas to arson. Without evidence that any of this was likely to occur, General DeWhitt insisted upon being given the authority to round up and remove all "enemy aliens" on the West Coast (Daniels, 1975).

President Franklin D. Roosevelt on February 19, 1942, in Executive Order 9066, provided General DeWhitt with the authority he sought. Roosevelt's Order made no specific reference to Japanese Americans, but clear authority was given to military commanders to designate areas in which any person, or all persons, could be excluded for purposes of national-security. These exclusion zones were understood to be equally applicable to citizens and non-citizens (Brooks, 1999). The Executive Order in effect represented the prevailing sentiment of political and military leaders throughout the country. The US Supreme Court supported Roosevelt's Order by ruling that the rights guaranteed to American citizens by the US Constitution could be suspended under conditions of war or threats to national security. Most Americans supported Roosevelt with the sentiment that precautions had to be taken to secure the West Coast and the nation.

Shortly after President Roosevelt's Order, General DeWhitt issued proclamations informing Japanese Americans that they would at some later point be removed from "Military Area No.1," and that anyone who had "enemy ancestry" was required to file a change of residence notice if they planned to move. From the headquarters of General DeWhitt, on May 3, 1942, an order was issued requiring all citizens and non-citizens of Japanese ancestry to report to Assembly Centres, run by the Army's Wartime Civil Control Administration (WCCA), where they would be detained and processed for transportation to Relocation Centres (Brookes, 1999).

General DeWhitt's evacuation order included all Americans with any trace of Japanese ancestry. The order even included children of Japanese ancestry who were adopted by non-Japanese parents. The massive evacuation was reminiscent of the brutal decision by President Andrew Jackson in 1830 to forcefully relocate all 
Cherokee Indians and other Native Americans living east of the Mississippi River in what is known as the "Trail of Fears". There were no formal charges levied against the Japanese Americans, there was no trial by jury, and there was not a shred of evidence of subversive activity (Grodzins, 1949). The forced relocation of Japanese Americans into concentration camp enclosures was an act born out of racist predilection.

The short notices given to Japanese Americans to report to assembly points for processing intensified their trauma. The advanced notice to report varied from only twenty-four hours in some areas to two weeks elsewhere. No provisions were made to assist Japanese Americans with the administration of their property and personal effects. Instead, they were only allowed to keep the personal effects they could carry with them. Their homes, cars, furniture, and other large assets, were sold for next to nothing. Japanese Americans suffered enormous economic and personal losses. Their social worlds began to crumble; their sense of well-being was seriously disturbed, and their future became very uncertain (Irons, 1983).

The living conditions at the thirteen Assembly Centres were appalling. The US government provided food, medical care, and basic education to the detainees (U.S. Department of the Interior, 1946). The detainees were however forced to live in crowded and unsanitary conditions like those of a concentration camp. The purpose of detention here was to give the War Relocation Authority (WRA) time to prepare ten permanent internment camps. Detainees were held in these provisional camps for periods ranging up to six month. Once the permanent internment camps were complete, the WRA began the massive relocation of detainees by train. Detainees were not given any information about their destination. They were hoarded onto trains under armed guard. The windows of the trains were covered and the detainees had to endure the journey without knowing anything about their destination or their collective fate.

It became clear that the conditions of their detention were in fact a form of incarceration (Tateishi, 1984). In essence, free American citizens were reduced to being prisoners of war in their own country (Levine, 1995). Though the US was also at war with Germany and Italy, German Americans and Italian Americans were not incarcerated like Japanese Americans. Despite the cruel context of the relocation, most did not resist but instead sought to demonstrate their loyalty by being cooperative. By the time that the evacuations to the permanent internment camps were complete, more than 120,000 persons of Japanese ancestry had been forcefully relocated. 
Throughout the internment process, most Japanese Americans remained cooperative and frequently expressed sentiments about their loyalty to the US. As doubts emerged over the prior assumption of a blanket disloyalty, questionnaires were distributed to residents of camps as a way of assessing their allegiance to the US. One question asked if respondents were willing to swear allegiance to the United States and to renounce any allegiance or obedience to the Emperor of Japan (Daniels, 1993). This was a surprising question to many who had never set foot in Japan. Males of draft age were also asked if they would serve in the armed forces. Families were torn apart over the conditions under which answers were sought to these questions. It was hard to escape the harsh absurdity that sought to draw allegiance from a population of people who were unfairly reduced to no more than criminals.

Males who refused to swear allegiance or to accept military service were removed from their families and shipped to the camp at Tulle Lake, California. This camp had been designated as a segregation camp for "troublemakers" and "the disloyal". Those who out of bitterness renounced their citizenship and indicated a desire to go to Japan after the war were also sent to Lake Tulle. The men who swore allegiance were given the option of volunteering or being drafted into military service. Those who went to the army were assigned to an all-Neisi unit, the $442^{\text {nd }}$ Regimental Combat Team. The irony of this development was that the unit fought with extraordinary courage and skill in some of the more ferocious battles of the war. The unit became the most highly decorated unit of WWII, as well as the most highly decorated unit of comparable size in US military history (Daniels, 1993).

As the tide of the war changed with the Battle of Midway in the spring of 1942, it was apparent that the US would eventually win the war. Japanese Americans were no longer a threat to national security; the fear that Japan would invade subsided, and there was an official recognition that a disastrous mistake had been made. The US Supreme Court reversed itself in declaring that citizens could not be detained without due process and that the internment of Japanese Americans was an illegal act. The Japanese Americans were now free to go. But where could they go? They had been deprived of their jobs, their homes, and their property. The personal cost of the evacuation was disastrous and the negative sentiments toward them had not diminished. The last internment camp was not closed until August 1948, although the exclusion order was rescinded entirely in January 1945. The fact that this occurred long before the war ended provides strong evidence against the notion that the exclusion was entirely a security measure. As Japanese Americans 
left the camps, they confronted the problem of picking up the pieces and rebuilding their lives in a country that was still hostile and unrepentant.

\section{Institutional violence and realignment}

The internment of Japanese Americans will stand as one of the darkest hours in American history. The failure of the rule of law to reign in the mood of collective anger and mass hysteria was a severe indictment of American political principles and values as expressed in the constitution. The straightforward political truth is that the institutions of American democracy failed to protect Japanese American citizens from the abnormal and extralegal contravention of their rights. The suspicion that pressed the state into action, alongside of the racial/ethnic animosities that supported such action, was unfounded and unwarranted.

The US had no convincing evidence then, and even now, that people of Japanese ancestry posed a security threat to its interests. The troubling essence of this observation, as it relates to state as arbiter of law and justice, is that the rule of law can be made subject to the demands of collective anger and mass hysteria in times of national trauma. Instead of finding a way to navigate the troubled waters of racialised suspicion after the bombing, the American state simply reflected and expressed the mood of collective anger and mass hysteria.

In a related sense, where the state (the Roosevelt administration in particular) should have acted prudently above the fray of unwarranted suspicion, it merely sought to preserve the interests of its majority constituency. In so doing, the state breached the democratic nature of its institutions and moved them toward political violence against a subgroup of citizens. The purpose of this strategy was irretrievably tied to the reactive-realist political interest of securing the nation-state at all costs. The evacuation of Japanese Americans was reactive-realist, or after the fact realism, as opposed to being classically predisposed and prepared for all political and military threats emanating from within and outside of the nation state. In this context, the internment of Japanese Americans was also a political scapegoat to obviate and deflect inept preparation for the attack on Pearl Harbour. We should, therefore, not loose sight of the dangerous political expediency that affords the state the latitude to suspend the rule of democratic law in times of trauma, irrespective of the influences of mass hysteria and collective anger.

We now know that collective trauma approximates the suspension of an orderly sense of being. Furthermore that trauma in general demands quick and 
accessible answers to the breach that has been suffered (Nytagodien and Neal, 2004). What is left now is to appraise how states can act to stymie the kind of fallout that led to the civil and human rights violations of Japanese American detainees. This is a difficult and controversial area of inquiry that has very relevant applications to the age of democratic consolidation we find ourselves living within. If the movement of people is a given condition of globalisation and, furthermore, if we are to accept that the post-cold war state is ever inclined to further heterogeneous identities, then the matter of creating race/ethnic scapegoats in times of collective traumas is a vexing and pressing problem.

In the case of Pearl Harbour, racism reduced all Japanese to stereotypes and accommodated the circumstances that led to the suspension of their constitutional rights. The tendency to exaggerate the fault lines that run through a nation-state thus become most acute in times of a national trauma. We are therefore pressed to appraise the cognitive and structural dysfunctions that frame the outcomes of national traumas. The purpose of such an appraisal would necessarily lend itself to the further consolidation of the rule of law and the unconditional perseverance of civil rights and human rights in the event of a national trauma. Where the state is found to be in pursuit of national security, such security cannot come at the expense of setting aside the rule of law and its emphasis on the protection of the individual rights to equality, freedom and justice. In fact, the very core of our democratic institutions must be conditioned, and reconditioned where need be, to be flexible enough to withstand the socio-political pressures that would run counter to the rule of law. The failure to observe the sanctity of these prescripts will inevitably lead to the kind of gross civil and human rights violations that occurred in the wake of Pearl Harbour.

\section{Retrospective evaluations}

In retrospect, the use of power and authority by the state to deprive citizens of their civil and human rights weighed heavy on the conscience of many Americans. Even before the Supreme Court declared the internment to be illegal, President Roosevelt, in a gesture suggesting that a mistake had been made, announced his intention to close the camps and to permit internees to leave. Earl Warren, who was later to become one of the nation's strongest advocates of civil rights, expressed deep regrets in his memoirs about the role he played, as Attorney General of California, in advocating the exclusion policy (Warren, 1977). 
Beginning in the 1960s, a younger generation of Japanese Americans that had been energised by the Civil Rights Movement organised what was known as the "Redress Movement." An effort was made to obtain a formal apology and reparations from the US government for incarceration during the war. The estimated losses for their parents and grandparents exceeded five to six billion dollars by 1942 standards. The first success of the movement occurred when President Ford proclaimed in Proclamation 4417 that the evacuation was wrong and that Japanese Americans were in fact loyal Americans (Proclamation 4417, 1976). The Commission on Wartime Relocation and Internment of Civilians (CWIRC), established by Congress concluded in a report entitled "Personal Justice Denied" that the internment was unjust and motivated by racism rather than military necessity (CWIRC, 1980).

The political battle for recognition of what the forced evacuation did to the lives of Japanese Americans would take almost three decades to receive official redress. The CWIRC called for five recommendations for redress in June 1983. These were: to issue an official apology; to secure a presidential pardon for those evacuees who violated statutes regulating their internment; congress was urged to be liberal and sympathetic about claims for restitution and status lost while interned; congress was urged to set aside research funding to study the causes and outcomes of the internment so that similar events could be avoided; and finally, that congress pay a one-time, tax-free compensation of $\$ 20,000$ (approximately R132, 000) to each internment survivor.

Though redress legislation was hotly debated under circumstances that blend congressional re-election concerns with interest group lobbying, the CWRIC recommendations were written into the Civil Liberties Act of 1988. On August 10, 1998 , President Ronald Reagan signed an order to pay reparations of $\$ 20,000$ to survivors of the internment camps. Redress payments were made starting on October 9, 1990. This date marked the passage of forty-eight years since Japanese Americans were detained, and seven years since the CWRIC recommended redress (Daniels et al, 1991). In so doing, a political battle over the place that Japanese Americans hold in the American nation was affirmed. That affirmation, however, is not without political controversy as almost half of those who were eligible for reparation died before they were eligible for reparation. In addition, those who were interned but were not American citizens were not eligible for compensation.

The socio-political fate of internees after Pearl Harbour still raises persistent, and troubling, concerns about the mood of mass hysteria and collective 
anger that are associated with national traumas. These concerns are central to our current age of heightened terrorist alert where subgroups in major democracies are often singled out unfairly as suspects aligned with subversive acts that have occurred. For example, from the fear engendered by the terrorist attack of $9 / 11$, the restrictions on civil liberties imposed by the Patriot Act (2001) were approved by Congress without debate or amendments (Cassell, 2004).

The trauma of the 9/11 terrorist attack evoked a new round of debates in the US on the internment of Japanese Americans more than sixty years ago. While some emphasised the importance of the historical precedent as a reminder of what to avoid in the current emergence, a few disagreed and argued that the internment was necessary as a national security measure. Machille Malkin (2004), expressed views shared by some of the more conservative members of congress when she advocated "ethnic profiling" and maintained that all Arab Americans should be rounded up and placed in internment camps.

Issues linked to the bending of legal boundaries and the reinterpretation of the rule of law is once again the centre of debate in the United States, France, and Britain. We cannot but accept that we live in times that are ripe for the kind of gross violations that occurred with the Japanese American internment. The question of whether it could happen again is more pressing now than ever before, particularly, in light of the 9/11 tragedy and the more recent commuter train bombings in Spain (3/11) and Britain (7/7). What is needed is prudent domestic and international leadership that seeks to reassert the necessity of binding all security concerns to the prerogatives of our universal human rights. This is the grand principle that must be drawn from the unjust internment of Japanese Americans during World War II.

\section{References}

Altheide, David L. 2002. Creating Fear: News and the Construction of Crisis. New York: Aldine de Gruyter.

Benedict, Ruth. 1989. The Chrysanthemum and the Sword: Patterns of Japanese Culture. Boston: Houghton Mifflin.

Benjamin, Thomas. 2000. La Revolucion: Mexico's Great Revolution as Memory Myth and History. Austin: University of Texas Press.

Berry, John A. and Carol Pott Berry. (eds.). 1999. Genocide in Rwanda: A Collective Memory. Washington D.C.: Howard University Press.

Brooks, Roy L. (ed.). 1999. When Sorry is Not Enough: The Controversy over Apologies and Reparations for Human Injustices. New York: New York University Press.

Brown, DeSoto. 1995. Hawaii Goes to War: Life in Hawaii from Pearl Harbor to Peace. Honolulu: Editions Limited. 
Browne, Ray B. and Arthur G. Neal. 2001. Ordinary Reactions to Extraordinary Events. Bowling Green, OH: Bowling Green State University Popular Press.

Cassell, Elaine. 2004. The War on Civil Liberties: How Bush and Ashcroft have Dismantled the Bill of Rights. Chicago: Lawrence Hill Books.

Commission on Wartime Relocation and Internment of Civilians (CWIRC), 1982. Personal Justice Denied. Washington D.C.: United States Government Printing Office.

Daniels, Roger. 1975. The Decision to Relocate the Japanese Americans. Philadelphia: J.B. Lippincott.

Daniels, Roger. 1993. Prisoners without Trial: Japanese Americans in World War II. New York: Hill and Wang.

Daniels, Roger; Sandra C. Taylor and Harry H. L. Kitano. (eds.). 1991. Japanese Americans: From Relocation to Redress, Revised Edition. Seattle: Washington University Press.

Grodzins, Morton. 1949. Americans Betrayed: Politics and the Japanese Evacuation. Chicago: University of Chicago Press.

Hearings before the Joint Committee on the Investigation of the Pear Harbour Attack, Part 39, 1946. Pear Harbour Attack. Washington D.C.: United States Government Printing Office.

Herman, Judith Lewis. 1997. Traumas and Recovery: The Aftermath of Violence from Domestic Abuse to Political Terror. New York: Basic Books.

Hochchild, A. 1999. King Leopold's Ghost. New York: Houghton Mifflin Co.

Hoehling, A. A. 1963. The Week Before Pearl Harbor. New York: W.W. Norton.

Igarashi, Yoshikuni. 2000. Bodies of Memory: Narratives of War in Postwar Japanese Culture, 1945-1970. Princeton: Princeton University Press.

Irons, Peter. 1983. Justice at War: The Story of Japanese American Internment Cases. Berkeley: University of California Press.

Levine, Ellen. 1995. A Fence Away from Freedom: Japanese Americans and World War II. New York: G.P. Putnam's Sons.

Lifton, Robert Jay and Eric Markusen. 1998. The Genocidal Mentality: Nazi Holocaust and Nuclear Threat. New York: Basic Books.

Malkin, Michelle. 2004. In Defense of Internment: The Case for 'Racial Profiling' in World War II and the War on Terror. Washington, DC: Regnery Publishing.

McWilliams, Cary. 1944. Prejudice: Japanese Americans: Symbols of Racial Intolerance. New York: Little Brown.

Neal, Arthur G. 2005. National Traumas and Collective Memory: Extraordinary Events in the American Experience. Armonk, NY: M. E. Sharpe.

Neuman, William L. 1963. America Encounters Japan: From Perry to MacArthur. New York: Harper Colophon.

Nytagodien, Ridwan Laher. 2003. Classroom Confrontations: Racism in South Africa and the United States. Safundi: The Journal of South African and American Comparative Studies, Issue 12, www.safundi.com 
Nytagodien, Ridwan Laher and Arthur G. Neal. 2004. Collective Trauma, Apologies, and the Politics of Memory. Journal of Human Rights, Vol. 3, No. 4: 466-475.

Prange, Gordon W. 1982. At Dawn We Slept: The Untold Story of Pearl Harbor. New York: Penguin Books.

Proclamation 4417, 1976. Confirming the Termination of the Executive Order Authorizing Japanese-American Internment during World War II. Washington D.C.: United States Government Printing Office.

Robinson, Greg. 2003. By Order of the President: FDR and the Internment of Japanese Americans. Cambridge, MA: Harvard University Press.

Robinson, Randall. 2000. The Debt: What America Owes to Blacks. New York: Dutton.

Rushbridger, James and Eric Nave. 1992. Betrayal at Pearl Harbor: How Churchill Lured Roosevelt into World War II. New York: Touchstone Books.

Selden, Kyoto and Selden, Mark. (eds.). 1989. The Atomic Bomb: Voices from Hiroshima and Nagasaki. Armonk, NY: M. E. Sharpe.

Shibuttani, Tamatsu. 1966. Improvised News: A Sociological Study of Rumor. Indianapolis: Bobbs-Merrill.

Silberstein, Sandra. 2002. War of Words: Language, Politics and 9/11. New York: Routledge.

Smith, Bradford. 1948. Americans from Japan. Philadelphia: J.B. Lippincott.

Smith, Geoffrey S. 1991. Racial Nativism: pp.79-87. In: Roger Daniels; Sandra C. Taylor and Harry H. L. Kitano. (eds.). Japanese Americans: From Relocation to Redress, Revised Edition. Seattle: Washington University Press.

Spalding, Matthew. 1998. A Sacred Union of Citizens: George Washington's Farewell Address and the American Character. Lanham, MD: Rowman \& Littlefield Publishers, Inc.

Tateishi, John. 1984. And Justice for All: An Oral History of the Japanese American Detention Camps. New York: Random House.

Toland, John. 1982. Infamy: Pearl Harbor and Its Aftermath. New York: Doubleday.

U.S. Department of the Interior, 1947. WRA: A Story of Human Conservation. Washington D.C.: United States Government Printing Office.

Warren, Earl. 1977. Memoirs of Chief Justice Earl Warren. New York: Doubleday. 